\title{
Elasticity-dependent response of malignant cells to viscous dissipation
}

\author{
Elisabeth E. Charrier ${ }^{1,2,5} \cdot$ Katarzyna Pogoda $^{1,3,5} \cdot{\text { Robin } \mathrm{Li}^{1} \cdot \text { Rebecca G. Wells }}^{2,5} \oplus \cdot$ Paul A. Janmey ${ }^{1,4,5}$
}

Received: 2 April 2020 / Accepted: 31 July 2020 / Published online: 12 August 2020

(C) The Author(s) 2020

\begin{abstract}
The stiffness of the cellular environment controls malignant cell phenotype and proliferation. However, the effect of viscous dissipation on these parameters has not yet been investigated, in part due to the lack of in vitro cell substrates reproducing the mechanical properties of normal tissues and tumors. In this article, we use a newly reported viscoelastic polyacrylamide gel cell substrate, and we characterize the impact of viscous dissipation on three malignant cell lines: DU145 and PC 3 derived from prostate and LN229 from brain. The spreading, motility and proliferation rates of these cells were analyzed on $1 \mathrm{kPa}$ and $5 \mathrm{kPa}$ elastic and viscoelastic gels. Surprisingly, the effect of substrate viscous dissipation on cell behavior depended on substrate stiffness for the three cell types tested. We conclude that viscoelasticity controls the spreading, proliferation and migration of malignant cells in vitro. These results highlight the critical role of viscous dissipation in the phenotype and proliferation of malignant cells, especially in stiff tumor environments.
\end{abstract}

Keywords Viscoelasticity $\cdot$ Malignant cell $\cdot$ Mechanosensing $\cdot$ Viscosity sensing

\section{Introduction}

Cell differentiation and proliferation are regulated by the biochemical and mechanical environment. Over the last two decades, numerous bio-inspired substrates for cell culture have been developed to reproduce the mechanical environment of biological tissues and understand how mechanical cues influence cell morphology and behavior. However, most of these bio-inspired materials are purely elastic soft

Elisabeth E. Charrier and Katarzyna Pogoda have equally contributed to this work.

Katarzyna Pogoda

katarzyna.pogoda@ifj.edu.pl

1 Institute for Medicine and Engineering and Center for Engineering MechanoBiology, University of Pennsylvania, Philadelphia, PA, USA

2 Division of Gastroenterology and Hepatology, Department of Medicine, Perelman School of Medicine, University of Pennsylvania, Philadelphia, PA, USA

3 Institute of Nuclear Physics Polish Academy of Sciences, 31342 Kraków, Poland

4 Department of Physiology, University of Pennsylvania, Philadelphia, PA, USA

5 Center for Engineering Mechanobiology, University of Pennsylvania, Philadelphia, PA, USA hydrogels that do not resemble biological tissues, which are viscoelastic (Denisin and Pruitt 2016; Engler et al. 2006) and have shear loss moduli $\left(G^{\prime \prime}\right)$ that are $10-20 \%$ of the storage moduli $\left(G^{\prime}\right)$ (Cheng et al. 2008; Pogoda et al. 2014; Mihai et al. 2015; Safshekan et al. 2017; Geerligs et al. 2008; Perepelyuk et al. 2016). The balance between $G^{\prime}$ and $G^{\prime \prime}$ is disturbed during pathological processes such as cancer (Levental et al. 2009; Visscher et al. 2016; Omari et al. 2015) and fibrosis (Chen et al. 2013; Deffieux et al. 2015) where tissue stiffness increases while the ratio $G^{\prime \prime} / G^{\prime}$ decreases (Perepelyuk et al. 2013).

Tumors and their microenvironments are often stiffer than surrounding normal tissues (Huang and Ingber 2005; Krouskop et al. 1998). This increased stiffness, quantified by an elastic modulus, promotes malignant cell proliferation (Paszek et al. 2005; Tilghman et al. 2010) and resistance to chemotherapy (Castells et al. 2012; Correia and Bissell 2012). Additionally, some tumors such as breast present a simultaneous increase in stiffness and loss of stress relaxation (Levental et al. 2010), whereas others such as gliomas do not appear to increase stiffness, but do increase viscous dissipation (Reiss-Zimmermann et al. 2015). Given the stimulatory effect of environmental mechanical properties on malignant cell proliferation and drug resistance (Pogoda et al. 2017; Zhang et al. 2017; Hui et al. 2017), it is critical 
to assess the effect of viscous dissipation on malignant cell phenotype to improve therapeutic strategies.

In this article, we use a new kind of soft viscoelastic polyacrylamide hydrogel (Charrier et al. 2018, 2020) that reproduces the mechanical properties of normal and tumor tissues. We used elastic and viscoelastic $1 \mathrm{kPa}$ and $5 \mathrm{kPa}$ gels to analyze the response of three malignant cell lines to substrate elasticity and viscosity and show that the cellular response to viscous dissipation is specific to each cell type and dependent on matrix stiffness.

\section{Results and discussion}

\subsection{Viscoelastic gels with independently tunable elasticity and viscosity}

Viscoelastic hydrogels are composed of linear polyacrylamide (PAA) molecules entangled in a cross-linked network of polyacrylamide (Fig. 1a). The formulation of the gels allows independent modification of their elasticity and viscosity. The elasticity is controlled by the amount of PAA cross-linked into a network; the viscosity is dependent on the amount of linear PAA sterically trapped inside this network (Table 1 and Fig. 1a). We formulated what we called $1 \mathrm{kPa}$ and $5 \mathrm{kPa}$ elastic and viscoelastic gels (Table 1) with loss
Table $11 \mathrm{kPa}$ and $5 \mathrm{kPa}$ elastic and viscoelastic gels average elastic $\left(G^{\prime}\right)$ and viscous $\left(G^{\prime \prime}\right)$ moduli at $1 \mathrm{rad} / \mathrm{s}$, and gel formulation

\begin{tabular}{lrrlll}
\hline Gel & $G^{\prime}(\mathrm{Pa})$ & $G^{\prime \prime}(\mathrm{Pa})$ & $\%$ acrylamide & $\begin{array}{l}\% \text { bis- } \\
\text { acryla- } \\
\text { mide }\end{array}$ & $\begin{array}{l}\% \\
\text { linear } \\
\text { PAA }\end{array}$ \\
\hline $1 \mathrm{kPa}$ elastic & 1600 & 1 & 4.5 & 0.1 & 0 \\
$\begin{array}{l}1 \mathrm{kPa} \text { viscoe- } \\
\text { lastic }\end{array}$ & 1590 & 206 & 5.5 & 0.1 & 4 \\
$5 \mathrm{kPa}$ elastic & 5600 & 11 & 8 & 0.1 & 0 \\
$5 \mathrm{kPa}$ viscoe- & 6300 & 490 & 8 & 0.15 & 4 \\
lastic & & & & & \\
\hline
\end{tabular}

$\left(G^{\prime \prime}\right) /$ storage $\left(G^{\prime}\right)$ modulus ratios of $13 \%$ and $8 \%$, respectively, when measured at $1 \mathrm{rad} / \mathrm{s}$ (Fig. 1d, e), which is similar to what is observed for biological tissues (Pogoda et al. 2014; Cheng et al. 2008; Mihai et al. 2015; Geerligs et al. 2008; Perepelyuk et al. 2016; Pogoda and Janmey 2018). $G^{\prime}$ and $G^{\prime \prime}$ of the gels were measured with a rheometer during the polymerization of the network by applying an oscillating shear stress to the gels (Fig. 1b, c); characterization was at $1 \mathrm{rad} / \mathrm{s}$ because this timescale was previously reported as relevant for cell mechanosensing at the steady state (Plotnikov et al. 2012; Chan and Odde 2008).

The stiffness of the gel depends on the amount of acrylamide polymerized in the network (Fig. 1 and
Fig. 1 Mechanical characterization of elastic and viscoelastic gels. a Cartoon representing the organization of polyacrylamide in the viscoelastic gels. b Evolution of $G^{\prime}$ and $G^{\prime \prime}$ over time during $1 \mathrm{kPa}$ gel polymerization. c Evolution of $G^{\prime}$ and $G^{\prime \prime}$ over time during $5 \mathrm{kPa}$ gel polymerization. d Average $G^{\prime}$ and $G^{\prime \prime}$ values for $1 \mathrm{kPa}$ elastic and viscoelastic gels at $1 \mathrm{rad} / \mathrm{s} . \mathrm{n}=5$ gels per condition. e Average $G^{\prime}$ and $G^{\prime \prime}$ values for $5 \mathrm{k} \mathrm{Pa}$ elastic and viscoelastic gels at $1 \mathrm{rad} / \mathrm{s}$. $\mathrm{n}=5$ gels per condition

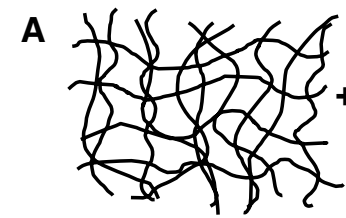

Crosslinked PAA (elastic)
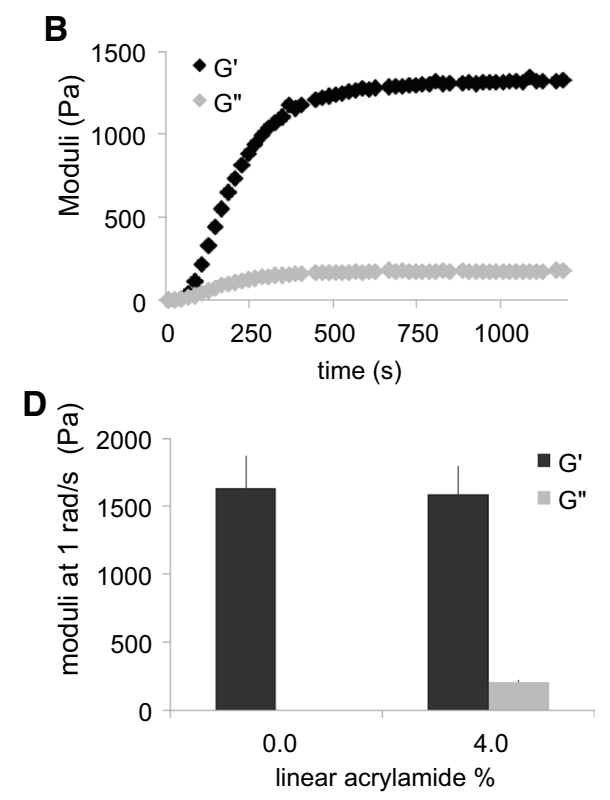

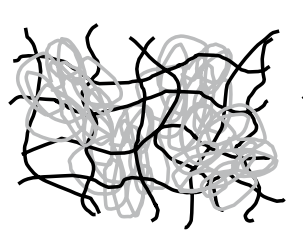

$1 \mathrm{kPa}$ viscoelastic gel
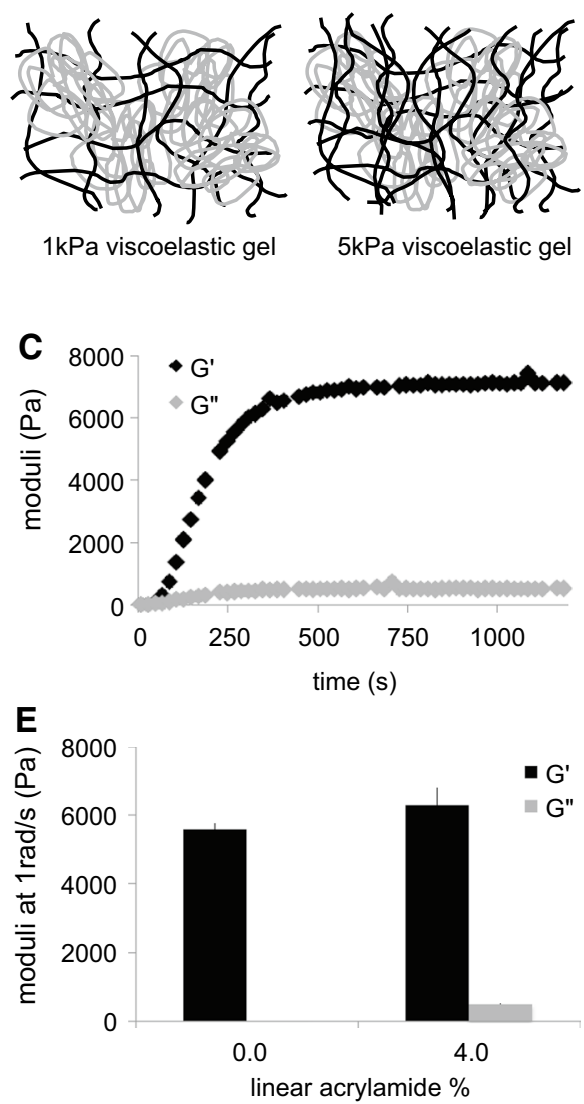
Table 1) such that gels containing about 5\% acrylamide have an elastic modulus of $\sim 1000$ to $1500 \mathrm{~Pa}$ (marked $1 \mathrm{kPa}$ ) and gels containing $8 \%$ acrylamide have an elastic modulus of 5-6 kPa (marked $5 \mathrm{kPa}$ ). During the polymerization of the PAA network, both $G^{\prime}$ and $G^{\prime \prime}$ increase over time (Fig. 1b, c). This result indicates that the loss moduli of the gels originate from the confinement of the linear PAA into a network. Additionally, the value of $G^{\prime \prime}$ is different for $1 \mathrm{kPa}$ gels and $5 \mathrm{kPa}$ gels, even though the amount of linear PAA in both gels is similar (Table 1). The value of $G^{\prime \prime}$ was correlated with that of $G^{\prime}$, indicating that the linear PAA confers its dissipative properties to the gel, to an extent that depends on its mesh size and therefore elastic modulus. The network of PAA participates in viscous dissipation by controlling the movement of the linear polymers, thereby affecting their relaxation inside the gel. These gels have been described as viscoelastic solids that exhibit stress relaxation under the application of a constant shear strain (Charrier et al. 2018).

In order to enable cell adhesion to the gels, acrylamide was copolymerized with acrylic-acid N-hydroxy-succinimide ester prior to polymerization. The resulting network contained activated monomers within the polymer chain that were covalently cross-linked to collagen I after incubation with the adhesion protein at $\mathrm{pH}=8.2$ to prevent the formation of collagen I bundles and ensure that the gels would be coated with monomers of collagen I.

\subsection{Cell spreading and morphology on viscoelastic gels}

We characterized the response to elasticity and viscous dissipation of three malignant epithelial cell lines from significantly different in vivo mechanical environments: the brain and bone. We used DU145 cells, which are prostate carcinoma cells derived from brain metastasis; PC3 cells, prostate carcinoma cells derived from bone metastasis; and LN229 cells, glioblastoma cells from primary tumors. By using these three cell types, we were able to test the response to viscosity of cells which in vivo had proliferated in a stiff and nearly purely elastic environment (PC3 cells), and those which had proliferated in a very soft and viscous environment (DU145 cells and LN229 cells).

We determined the projected area of the three cell types $24 \mathrm{~h}$ after plating on $1 \mathrm{kPa}$ and $5 \mathrm{kPa}$ elastic and viscoelastic gels (Figs. 2, 3 and 4). On purely elastic gels, DU145 cells were larger when $G^{\prime}$ was $5 \mathrm{kPa}$ than when it was $1 \mathrm{kPa}$, which demonstrates their ability to sense and respond to stiffness. On $1 \mathrm{kPa}$ gels, DU145 cells had a similar area and round morphology, regardless of whether the gels were purely elastic (Circ $=0.90 \pm 0.05)$ or viscoelastic (Circ $=0.91 \pm 0.07)$ (Fig. 2b). On $5 \mathrm{kPa}$ gels, however, DU145 cells were well spread and more elongated when the gels were elastic $(\mathrm{Circ}=0.86 \pm 0.15)$, but they remained
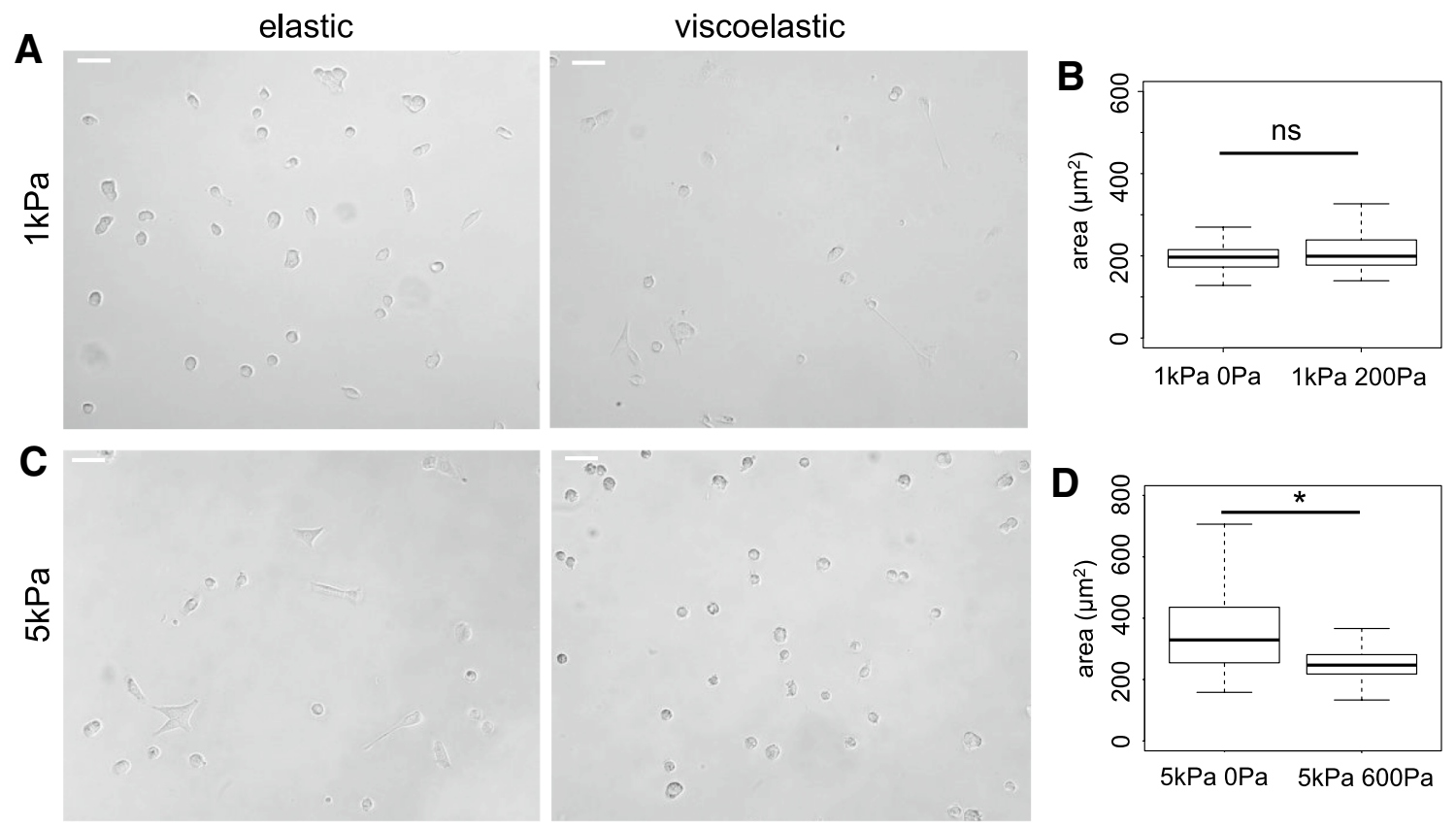

Fig. 2 Morphology of DU145 prostate cells on $1 \mathrm{kPa}$ elastic $\left(G^{\prime}=1 \mathrm{kPa} ; G^{\prime \prime}=0 \mathrm{~Pa}\right)$, viscoelastic $(1 \mathrm{kPa} ; 200 \mathrm{~Pa}), 5 \mathrm{kPa}$ elastic $(5 \mathrm{kPa} ; 0 \mathrm{~Pa})$ and viscoelastic $(5 \mathrm{kPa} ; 600 \mathrm{~Pa})$ gels. a Bright-field images of DU145 cells after $24 \mathrm{~h}$ on $1 \mathrm{kPa}$ gels. Scale bar $=50 \mu \mathrm{m}$. b
Average area of DU145 cells after $24 \mathrm{~h}$ on soft $1 \mathrm{kPa}$ elastic and viscoelastic gels, $* \mathrm{p}<0.001$. c Bright field images of DU145 cells after $24 \mathrm{~h}$ on $5 \mathrm{kPa}$ gels. Scale bar $=50 \mu \mathrm{m}$. d Average area of DU145 cells after $24 \mathrm{~h}$ on $5 \mathrm{kPa}$ elastic and viscoelastic gels, ${ }^{*} \mathrm{p}<0.001$ 

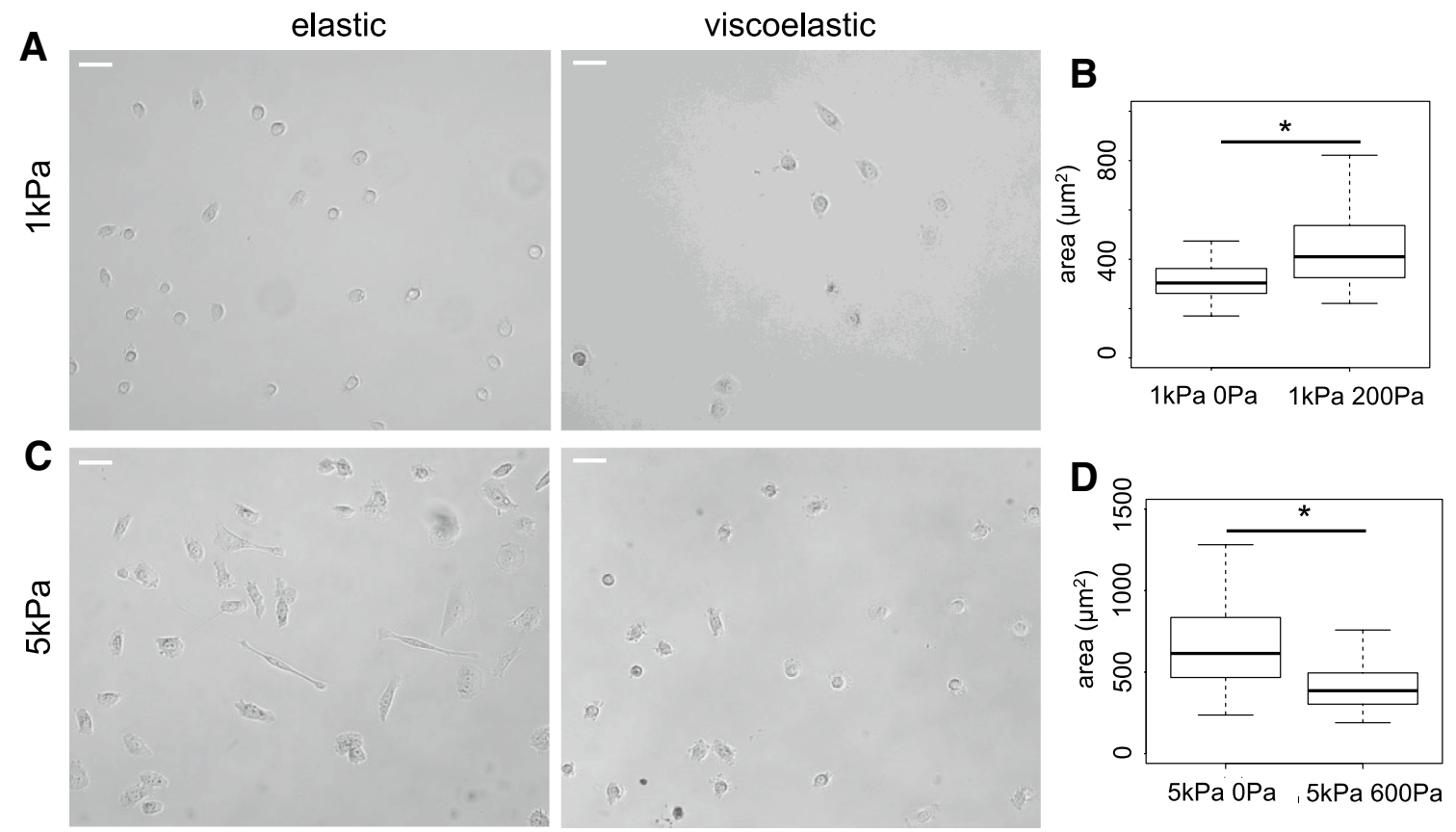

Fig. 3 Morphology of PC3 cells on $1 \mathrm{kPa}$ and $5 \mathrm{kPa}$ elastic and viscoelastic gels. a Bright field images of PC3 cells after $24 \mathrm{~h}$ on 1 $\mathrm{kPa}$ PAA gels. Scale bar $=50 \mu \mathrm{m}$. b Average area of PC3 cells after $24 \mathrm{~h}$ on $1 \mathrm{kPa}$ elastic and viscoelastic gels, ${ }^{*} \mathrm{p}<0.001$. c Bright field images of PC3 cells after $24 \mathrm{~h}$ on $5 \mathrm{kPa}$ gels. Scale bar $=50 \mu \mathrm{m}$. d Average area of PC 3 cells after $24 \mathrm{~h}$ on $5 \mathrm{kPa}$ elastic and viscoelastic gels, ${ }^{*} \mathrm{p}<0.001$
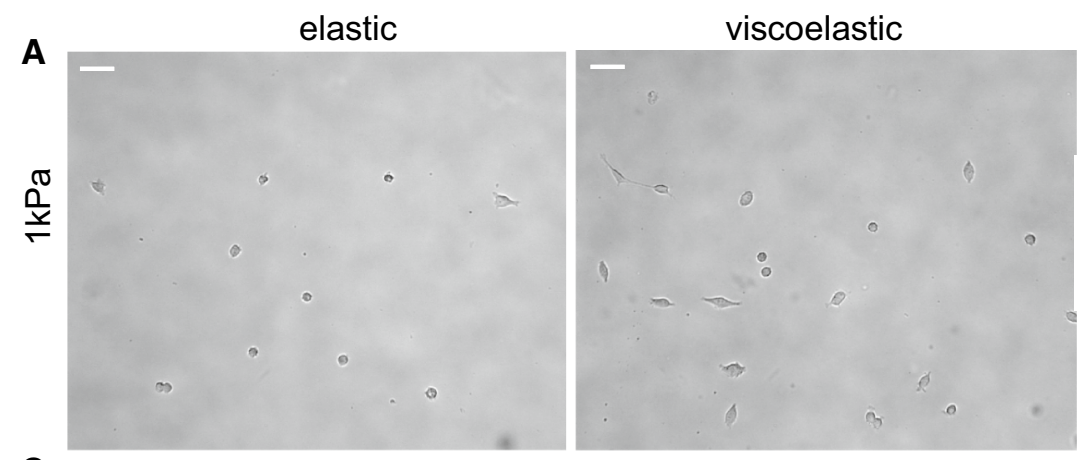

B
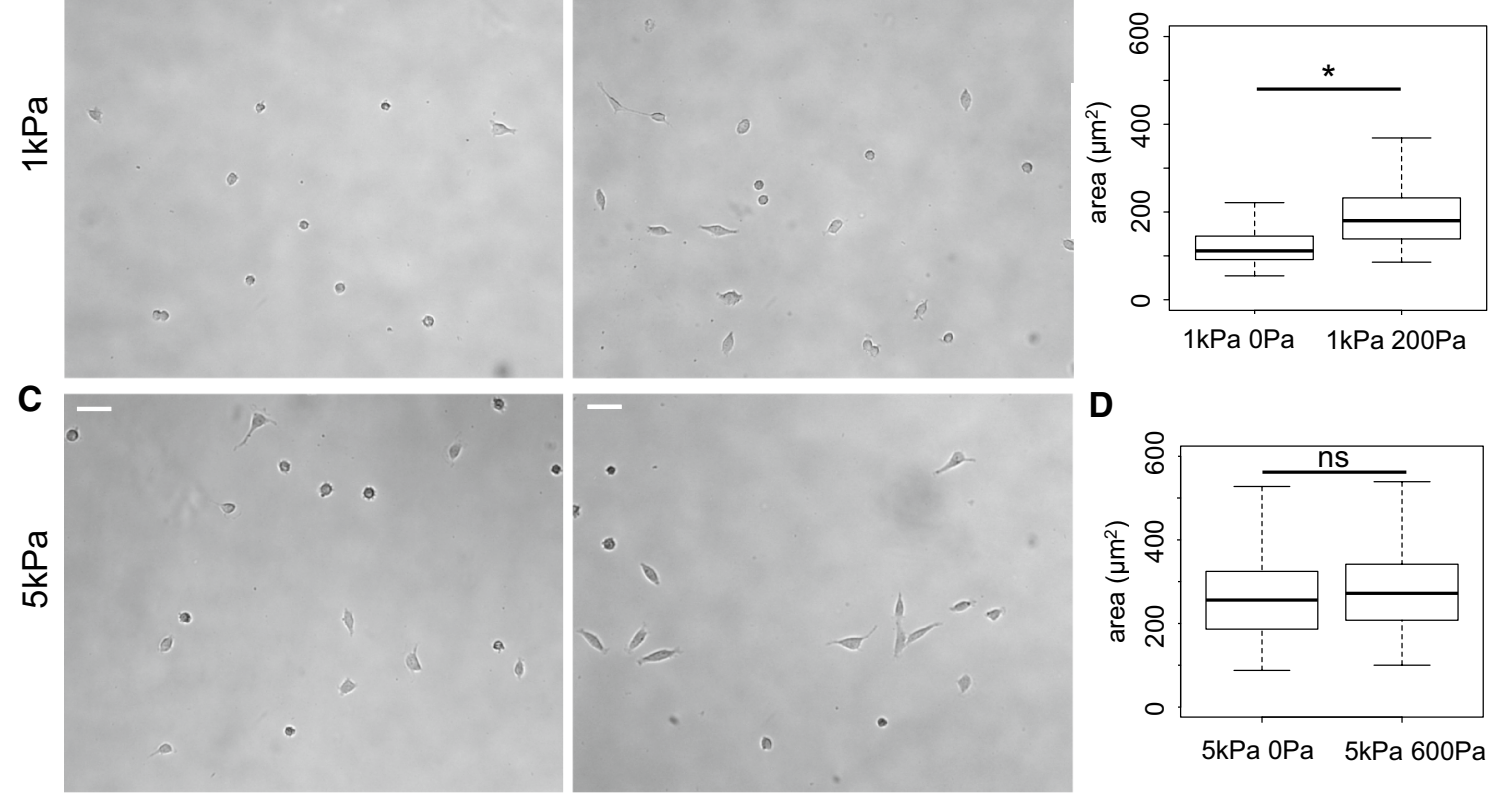

\section{D}

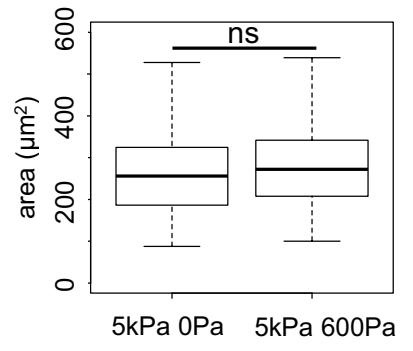

Fig. 4 Morphology of LN229 cells on $1 \mathrm{kPa}$ and $5 \mathrm{kPa}$ elastic and viscoelastic gels. a Bright field images of LN229 cells after $24 \mathrm{~h}$ on $1 \mathrm{kPa}$ PAA gels. Scale bar $=50 \mu \mathrm{m}$. b Average area of LN229 cells after $24 \mathrm{~h}$ on $1 \mathrm{kPa}$ elastic and viscoelastic gels, $* \mathrm{p}<0.001$. c

round and small on viscoelastic gels ( Circ $=0.93 \pm 0.05)$ (Fig. 2d). On both $1 \mathrm{kPa}$ and $5 \mathrm{kPa}$ viscoelastic gels, the
Bright field images of LN229 cells after $24 \mathrm{~h}$ on $5 \mathrm{kPa}$ gels. Scale bar $=50 \mu \mathrm{m}$. d Average area of LN229 cells after $24 \mathrm{~h}$ on $5 \mathrm{kPa}$ elastic and viscoelastic gels, ${ }^{*} \mathrm{p}<0.001$

spreading area of DU145 cells was around $250 \mu \mathrm{m}^{2}$, showing that, surprisingly, DU145 cell spreading is not affected by 
the elastic modulus of the substrate in a viscoelastic environment (Fig. 2b).

PC3 cells respond to elasticity similarly to DU145 cells, with increased cell spreading in response to increased elastic modulus of their substrate (Fig. 3) as previously shown (Kraning-Rush et al. 2012). The effect of viscous dissipation on PC3 cell spreading depends on the elastic modulus of the hydrogel. On $1 \mathrm{kPa}$ gels, PC3 cells spread significantly more when gels were viscoelastic rather than purely elastic with slightly more elongated morphology $(\mathrm{Circ}=0.88 \pm 0.09$ on viscoelastic and Circ $=0.93 \pm 0.03$ on elastic gels) (Fig. 3b). On $5 \mathrm{kPa}$ gels, PC3 cell area was significantly smaller, and cells exhibited a rounder morphology on viscoelastic gels $($ Circ $=0.89 \pm 0.07)$ than on elastic gels $($ Circ $=0.73 \pm 0.21)$ (Fig. 3c). PC3 cells responded in opposite ways to viscous dissipation on soft $1 \mathrm{kPa}$ and on stiffer $5 \mathrm{kPa}$ gels.

Similar to the response of PC3 cells, LN229 cell area is larger on $5 \mathrm{kPa}$ than on $1 \mathrm{kPa}$ elastic gels (Fig. 4). This is consistent with previous observations that multiple glioma cell lines, including LN229, are substrate rigidity-sensitive and do not spread and elongate on soft hydrogels (Ulrich et al. 2009; Pogoda et al. 2017). LN229 cells respond differently to viscous dissipation as a function of substrate elasticity compared to DU145 and PC3 cells. LN229 cells spread significantly more and exhibit more elongated morphology (Circ $=0,61 \pm 0,2)$ on $1 \mathrm{kPa}$ viscoelastic gels than on $1 \mathrm{kPa}$ elastic gels (Circ $=0,87 \pm 0,1)$ (Fig. 4b), while they spread similarly on both types of $5 \mathrm{kPa}$ gels with more elongated shape on viscoelastic ( $\operatorname{Circ}=0,47 \pm 0,17)$ than elastic gels $($ Circ $=0,59 \pm 0,22)($ Fig. $4 d)$.

For all cell lines studied, an increase in elastic modulus from 1 to $5 \mathrm{kPa}$ was associated with an increase in spreading, as previously observed for other types of the cells (Mih et al. 2011; Engler et al. 2004; Bangasser et al. 2017; Pogoda et al. 2017). Many cell types present a biphasic response to elasticity (Bangasser et al. 2017), with an optimal spreading elasticity that is specific to each cell type (Kostic et al. 2009). On viscoelastic substrates, the cellular response to mechanical cues from the environment becomes more complex as energy dissipation through the underlying substrate occurs (Chaudhuri et al. 2015; Charrier et al. 2018). Our data suggest that the response of malignant cells to viscoelastic materials displays at least two regimes, depending on the elastic moduli of the substrates (Figs. 2, 3 and 4). At low elasticity, viscous dissipation tends to favor cell spreading by increasing the overall stiffness perceived by cells (Gong et al. 2018). At high stiffness, viscous dissipation tends to prevent spreading, presumably by dissipating a part of the cellular energy through focal adhesions and thus lowering the adhesion strength of cells to their substrate. The elasticity at which the effect of viscosity transitions from promoting to limiting cell spreading seems to be cell type specific. We conclude that cell spreading on a viscoelastic solid is controlled by an interplay between the elastic and the viscous moduli of the substrate.

\subsection{Cell motility on elastic and viscoelastic gels}

In vivo, malignant cells from tumors can migrate through tissues to establish secondary tumors; as a consequence, the migratory patterns of malignant cells are an important part of their phenotype. The mechanical environment of malignant cells regulates their locomotion, and an increase in stiffness often, but not always, correlates with increased motility (Pathak and Kumar 2012; Pogoda et al. 2017; Ulrich et al. 2009).

We observed that PC3 and LN229 cell migration speed was sensitive to elastic modulus. These cell types were faster on $5 \mathrm{kPa}$ than on $1 \mathrm{kPa}$ elastic gels (Fig. 5). However, DU145 cells had similar speed on $1 \mathrm{kPa}$ and $5 \mathrm{kPa}$ elastic gels. We then analyzed the effect of viscous dissipation on cell motility. The two prostate cell lines (DU145 and PC3) responded to viscosity in a similar way, showing decreased motility on viscoelastic substrates. The glioma cells (LN229) had similar motility on elastic and viscoelastic gels of the same elastic modulus.
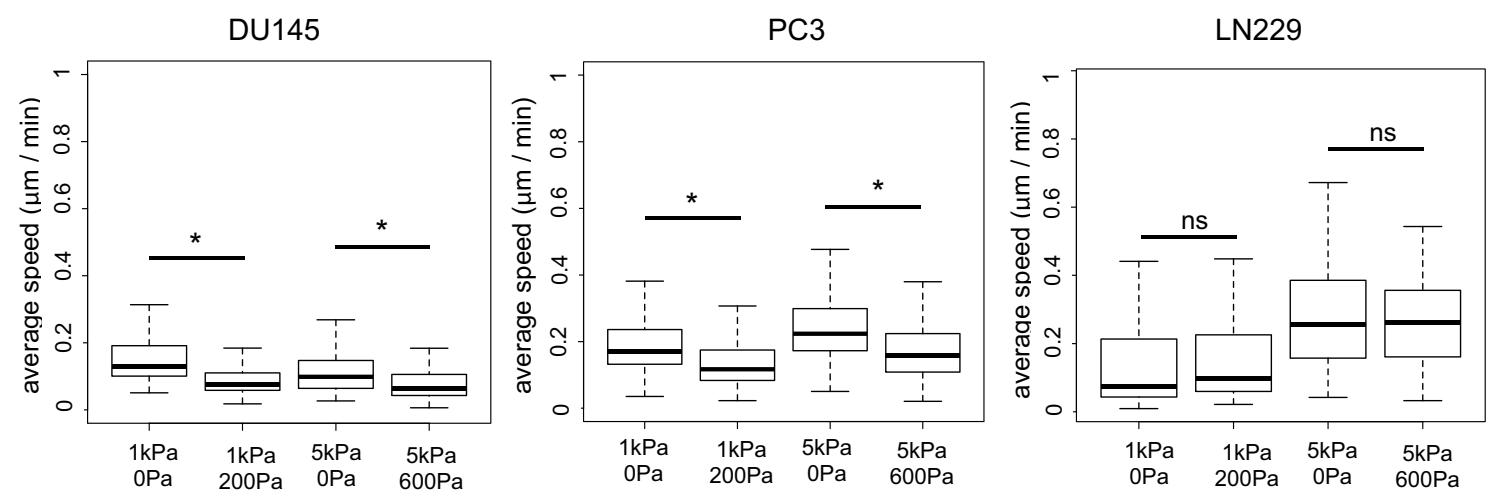

Fig. 5 Average motility speed of the three types of malignant cells on soft elastic and viscoelastic hydrogels 
As previously shown, viscoelasticity impaired the formation of mature focal adhesions (Cameron et al. 2011; Charrier et al. 2018) and thus might inhibit cell migration by preventing the establishment of the stable contacts with the substrate required to push the cell forward (Nagano et al. 2012). Moreover, the contractile forces produced by the actomyosin system regulate cell migration. Dissipating part of this contractile energy through the substrate might decrease the amount of force available to move the cell and thus might slow down migration similar to the effect of actomyosin inhibitors (Ivkovic et al. 2012).

Migration and spreading have been reported to be correlated on elastic substrates (Tilghman et al. 2010) through the control of focal adhesion (FA) size (Kim and Wirtz 2013). Cells on viscoelastic substrates form smaller FAs than on elastic substrates of the same elasticity (Charrier et al. 2018; Cameron et al. 2011). The formation of FAs and therefore the rate and extent of spreading depend on the relative rates or engagement of the adhesion complexes, motors, an adapter proteins (clutches) for the FA. A recent model that integrates viscous and elastic responses of the substrate with the on and off rates of molecular clutches predicts either increased or decreased spreading of cells in viscoelastic compared to elastic substrates, depending on the relative magnitudes of the relaxation times of the substrate and the proteins within the FA. Since the complement of molecular clutches including talin, filamin, vinculin and other proteins is unique to each cell type and might change as the stiffness or viscosity of the substrate changes, it is reasonable that different cell types can have opposite responses to viscosity depending on the magnitude of the elastic modulus and the nature of the adhesion receptors. There are insufficient quantitative data for the kinetic constants and amounts of FA proteins in different cell types, so direct application of this model to compare different cell types is not yet feasible. However, it is important to highlight that these mechanisms exhibit strong cell-type dependency, as the specific characteristics of a cell type will define how it interacts with its substrate (Webb et al. 2000).

\subsection{Cell proliferation on elastic and viscoelastic gels}

Stiff matrices often favor cell proliferation while soft substrates trigger growth-arrest (Klein et al. 2009; Tilghman et al. 2010; Ulrich et al. 2009; Mih et al. 2011). If malignant cell growth on hydrogels correlates with the rate of tumor growth in vivo (Tilghman et al. 2010), we speculated that the viscosity of soft tissues could also affect the cell proliferation rate in vivo because tumor tissues are stiffer than the surrounding normal tissue and characterized by altered viscous dissipation (Levental et al. 2010). We therefore tested whether viscoelasticity affects tumor cell proliferation in vitro. The three cell lines were cultivated on elastic and viscoelastic gels for 4 days, and the average doubling time of the cell population was quantified (Fig. 6).

We were not able to study the proliferation of DU145 cells as their number did not increase over time on hydrogels in any condition tested. This was unexpected, as these cells proliferate in vivo to establish secondary tumors in the very soft environment of the brain. However, on hydrogel substrates, the cells are able to adhere only by receptors to the single protein, collagen in this case, covalently linked to the gel surface; in vivo as well as on glass or plastic, there are likely to be multiple types of surface-bound receptors required to drive proliferation. Alternatively, since soft substrates have been reported to promote apoptosis (Leight et al. 2012; Tilghman et al. 2010), the lack of proliferation of DU145 cells might also be partially due to the programmed death of part of the population.

No proliferation was observed for PC3 cells on $1 \mathrm{kPa}$ gels, and we hypothesize that $1 \mathrm{kPa}$ is too soft to activate their proliferation. However, PC3 cells were able to proliferate on $5 \mathrm{kPa}$ gels and interestingly they proliferated faster on viscoelastic gels than on elastic gels. PC3 cell growth was previously described as rigidity-independent (Tilghman et al. 2010) but our results demonstrate that PC3 cells respond to mechanical changes affecting the viscoelasticity
Fig. 6 Average doubling time of PC3 (A) and LN229 (B) cells cultivated on elastic or viscoelastic soft PAA hydrogels
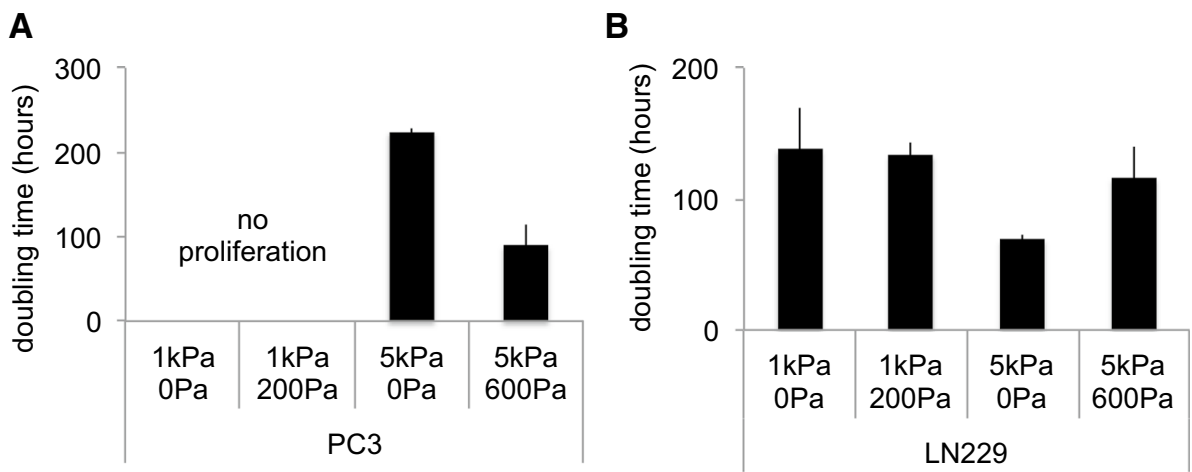
of the matrix. We hypothesize that the elastic and the viscous moduli are sensed through different cellular pathways.

LN229 cells proliferated on all the substrates tested. Glioblastoma cells have been reported to grow faster on stiff substrates (Pogoda et al. 2017; Ulrich et al. 2009). Our results are in agreement with these observations as LN229 cells proliferate faster on $5 \mathrm{kPa}$ elastic gels than on $1 \mathrm{kPa}$ elastic gels. LN229 growth was comparable on $1 \mathrm{kPa}$ elastic and viscoelastic gels, while on $5 \mathrm{kPa}$ gels cell proliferation was significantly slowed by viscous dissipation.

In summary, proliferation analyses of the three cell lines showed that the effect of viscous dissipation is different for each cell type and not simply dependent on matrix elasticity. This observation was surprising given that population doubling time has been previously reported to correlate with cell spreading and adhesion (Mih et al. 2012; Ulrich et al. 2009; Pogoda et al. 2017). However, our data suggest that viscous dissipation could be a powerful regulator of malignant cell phenotype and proliferation, especially in tumor environments presenting alterations of both elastic and viscous moduli (Levental et al. 2010).

\section{Conclusions}

We describe here the use of a newly developed viscoelastic hydrogel, which reproduces the viscoelasticity of biological tissues and is suitable for the culture of multiple cell types. By cultivating malignant cells of different origins on this material, we showed that the impact of viscous dissipation on cell phenotype depends on both substrate elastic modulus and cell type. All three types of cancer cells PC3, DU145 and LN229 respond to viscoelasticity of the substrate at least at two regimes, depending on the elastic moduli $G^{\prime}$ of the substrates in terms of morphology, motility and proliferation (different viscosity sensing at $1 \mathrm{kPa}$ and $5 \mathrm{kPa}$ elasticity, Table 2). Moreover, viscous dissipation modulates the cellular response to elasticity in a cell type-dependent manner; the response is more complex than cells sensing viscoelastic substrates as softer. This innovative material has potential to reveal the role of viscous dissipation in pathological contexts such as tumor progression.

\section{Methods}

\subsection{Polyacrylamide gels}

Viscoelastic PAA gels are made in two steps. First, the linear PAA is polymerized. Second, the network of PAA is polymerized around these linear molecules of PAA.

The linear solution is obtained by adding $0.05 \%$ TEMED and $0.024 \%$ ammonium persulfate to a PAA $5 \%(\mathrm{w} / \mathrm{v})$
Table 2 Summary of the stiffness-dependent viscosity sensing by the PC3, Du145 and LN229 cells in terms of their ability to spread (morphology), migrate (motility) and grow (proliferation)

\begin{tabular}{llll}
\hline & Viscosity sensing at & Viscosity sensing at & \\
& $1 \mathrm{kPa}$ stiffness & $5 \mathrm{kPa}$ stiffness & \\
\hline PC3 & Yes & Yes & Morphology \\
DU145 & No & Yes & \\
LN229 & Yes & No & Motility \\
PC3 & Yes & Yes & \\
DU145 & Yes & Yes & Proliferation \\
LN229 & No & No & \\
PC3 & - & Yes & \\
DU145 & - & - & \\
LN229 & No & Yes & \\
\hline
\end{tabular}

-Depicts the conditions were no proliferation was observed

acrylamide aqueous solution which was previously degassed and polymerized overnight at $37^{\circ} \mathrm{C}$. The resulting viscous fluid contains long linear PAA molecules and can be stored at $4{ }^{\circ} \mathrm{C}$ protected from light.

To obtain the network of PAA, $300 \mu \mathrm{L}$ of linear PAA solution was mixed with acrylamide, bis-acrylamide and $\mathrm{H}_{2} \mathrm{O}$ at a final volume of $500 \mu \mathrm{L}$. Polymerization was triggered by adding $1.25 \mu \mathrm{L}$ TEMED and $3.75 \mu \mathrm{L} \mathrm{10 \%} \mathrm{ammo-}$ nium persulfate to the $500 \mu \mathrm{L}$ of gel mix. The gel was polymerized for $30 \mathrm{~min}$ at room temperature and rinsed three times with PBS. Table 1 describes the formulation of the $1 \mathrm{kPa}$ and $5 \mathrm{kPa}$ gels.

\subsection{Rheology}

Rheology experiments were performed with a Kinexus stress-controlled rheometer (Malvern) and an RFS3 straincontrolled rheometer (TA Instruments) with a $20 \mathrm{~mm}$ circular parallel-plate geometry. The gels were polymerized for $30 \mathrm{~min}$ between the plates of the rheometer before starting the measurements. The evolution of $G^{\prime}$ and $G^{\prime \prime}$ during polymerization was followed by applying a $2 \%$ shear strain at the frequency of $1 \mathrm{rad} / \mathrm{s}$ until the values of $G^{\prime}$ and $G^{\prime \prime}$ reached a plateau.

\subsection{Gel functionalization}

To cross-link collagen I to the gel, $50 \mu \mathrm{L}$ of $4 \%$ acrylic-acid $\mathrm{N}$-hydroxy-succinimide ester (NHS) in DMSO was added to $500 \mu \mathrm{L}$ of unpolymerized acrylamide and bis-acrylamide gel solution. NHS coupled to the acrylate monomers, becomes reactive at high $\mathrm{pH}$ and can covalently bind proteins such as collagen I. This method ensured specific activation of the network of PAA as only monomers within the network are activated. The linear PAA previously polymerized is inert and thus will not present collagen I. Gels were functionalized 
with a solution of rat tail collagen I (Corning) at $0.1 \mathrm{mg} / \mathrm{mL}$ in $50 \mathrm{mM}$ HEPES buffer at $\mathrm{pH}=8.2$. The $\mathrm{pH}$ was carefully controlled to ensure that collagen I monomers were crosslinked to the network of PAA.

\subsection{Cell culture}

DU145, PC3 and LN229 cell lines were purchased from the ATCC and were maintained in RPMI (Gibco) medium (DU145 and PC3) or DMEM (Sigma) medium (LN229) supplemented with $10 \%$ fetal bovine serum (ATCC) and $1 \%$ of penicillin/streptomycin (Gibco) at $37{ }^{\circ} \mathrm{C}$ and $5 \% \mathrm{CO}_{2}$. For experiments, cells were plated at a density of 15,000 cells/ $\mathrm{cm}^{2}$ on PAA hydrogels in a volume of $100 \mu \mathrm{L}$ to ensure that the cells were in contact with the gel.

\subsection{Cell morphology analysis}

After $24 \mathrm{~h}$ of cell growth, bright-field images were taken with a Leica DMIRE2 inverted microscope (Leica) equipped with a Hamamatsu camera, and single-cell areas were manually traced using ImageJ software. Cell circularity was determined using the formula Circ $=4 \pi\left(\frac{\text { area }}{\text { perimeter }^{2}}\right)$. Circularity value of 1.0 indicates a perfect circle. Approximately 100 cells per condition were analyzed.

\subsection{Cell migration experiment}

The migration speed of cells growing on gels was determined with time-lapse microscopy over a period of $4 \mathrm{~h}$. A Tokai-Hit Imaging Chamber (Tokai Hit, Shizuoka-ken, Japan) that maintained a humid $37{ }^{\circ} \mathrm{C}$ and $5 \% \mathrm{CO}_{2}$ environment was first equilibrated for $1 \mathrm{~h}$. After $24 \mathrm{~h}$ of seeding, cultures were placed inside the chamber mounted on a Leica DMIRE2 inverted microscope equipped with an ASI $x / y / z$ stage (BioVision Technologies) and a Hamamatsu camera; a $10 \times$ air lens was used for image sequence recording. Cell migration speed $v$ (length of the total trajectory $d$ divided by time $t$ ) was calculated by tracing the $(x, y)$ position of the center of the cell at every image using ImageJ Software (NIH) and the Manual Tracking plug-in (https:// imagej.nih.gov/ij/). Minimum 70 cells per condition were analyzed.

\subsection{Cell proliferation experiment}

Cells were plated on gels for $24 \mathrm{~h}$, and then low-magnification bright-field images were taken. After $48 \mathrm{~h}$ and $72 \mathrm{~h}$, images were taken again at the exact same positions. The number of cells was counted for each time point. The evolution of the number of cells over three days was then fitted with an exponential model: $y(t)=y_{0} \mathrm{e}^{k t}$, where $y_{0}$ is the cell number at the time point $t_{0}, k$ is the growth constant and $t$ is time. Population doubling time $\left(t_{\mathrm{d}}\right)$ was calculated using the equation $t_{\mathrm{d}}=\frac{\ln 2}{k}$, as previously described (Pogoda et al. 2017).

\subsection{Statistical analysis}

Each experiment was performed at least in triplicate. Nonparametric multiple comparisons for relative contrast effects test (R software package) using Tukey's method with 95\% confidence interval were used to confirm statistical differences between the measured quantities. Denotations: $*, P \leq 0.05$; ** $P \leq 0.01$; ***, $P \leq 0.001$; ns, $P>0.05$, no significant differences.

Acknowledgements The authors would like to thanks Katrina Cruz, LiKang Chin, Anne Van Oosten and Lin Luda for their help and advice.

Authors' contributions EEC contributed to conceptualization, methodology, investigation (prostate cancer cells), data curation and writing-original draft preparation. KP contributed to conceptualization, methodology, investigation (glioblastoma cells), writing-reviewing and editing. RL was involved in investigation. RGW was involved in supervision and writing - reviewing and editing. PAJ was involved in conceptualization, project administration, funding acquisition, supervision and writing-reviewing and editing.

Funding This work was funded by the National Institutes of Health (R01EB017753) and the NSF Center for Engineering Mechanobiology (CMMI-154857). KP was supported by the National Science Center, Poland, under Grant No. UMO-2017/26/D/ST4/00997.

\section{Compliance with ethical standards}

Conflict of interest The authors declare that they have no conflict of interest.

Open Access This article is licensed under a Creative Commons Attribution 4.0 International License, which permits use, sharing, adaptation, distribution and reproduction in any medium or format, as long as you give appropriate credit to the original author(s) and the source, provide a link to the Creative Commons licence, and indicate if changes were made. The images or other third party material in this article are included in the article's Creative Commons licence, unless indicated otherwise in a credit line to the material. If material is not included in the article's Creative Commons licence and your intended use is not permitted by statutory regulation or exceeds the permitted use, you will need to obtain permission directly from the copyright holder. To view a copy of this licence, visit http://creativecommons.org/licenses/by/4.0/.

\section{References}

Bangasser BL, Shamsan GA, Chan CE, Opoku KN, Tüzel E, Schlichtmann BW, Kasim JA et al (2017) Shifting the optimal stiffness for cell migration. Nat Commun 8(May):15313. https://doi. org/10.1038/ncomms 15313 
Cameron AR, Frith JE, Cooper-White JJ (2011) The influence of substrate creep on mesenchymal stem cell behaviour and phenotype. Biomaterials 32(26):5979-5993. https://doi.org/10.1016/j.bioma terials.2011.04.003

Castells M, Thibault B, Delord J-P, Couderc B (2012) Implication of tumor microenvironment in chemoresistance: tumor-associated stromal cells protect tumor cells from cell death. Int J Mol Sci 13(8):9545-9571. https://doi.org/10.3390/ijms 13089545

Chan CE, Odde DJ (2008) Traction dynamics of filopodia on compliant substrates. Science (New York, N.Y.) 322(5908):1687-91. https ://doi.org/10.1126/science.1163595

Charrier EE, Pogoda K, Li R, Park CY, Fredberg JJ, Janmey PA (2020) A novel method to make viscoelastic polyacrylamide gels for cell culture and traction force microscopy. APL Bioeng 4(3):036104. https://doi.org/10.1063/5.0002750

Charrier EE, Pogoda K, Wells RG, Janmey PA (2018) Control of cell morphology and differentiation by substrates with independently tunable elasticity and viscous dissipation. Nat Commun 9(1):449. https://doi.org/10.1038/s41467-018-02906-9

Chaudhuri O, Gu L, Darnell M, Klumpers D, Bencherif SA, Weaver JC, Huebsch N, Mooney DJ (2015) Substrate stress relaxation regulates cell spreading. Nat Commun 6(February):6364. https ://doi.org/10.1038/ncomms7365

Chen X, Shen Y, Zheng Y, Lin H, Guo Y, Zhu Y, Zhang X, Wang T, Chen S (2013) Quantification of liver viscoelasticity with acoustic radiation force: a study of hepatic fibrosis in a rat model. Ultrasound Med Biol 39(11):2091-2102. https://doi. org/10.1016/j.ultrasmedbio.2013.05.020

Cheng S, Clarke EC, Bilston LE (2008) Rheological properties of the tissues of the central nervous system: a review. Med Eng Phys 30(10):1318-1337. https://doi.org/10.1016/j.meden gphy.2008.06.003

Correia AL, Bissell MJ (2012) The tumor microenvironment is a dominant force in multidrug resistance. Drug Resist Updat Rev Comment Antimicrob Anticancer Chemother 15:39-49. https ://doi.org/10.1016/j.drup.2012.01.006

Deffieux T, Gennisson J-L, Bousquet L, Corouge M, Cosconea S, Amroun D, Tripon S et al (2015) Investigating liver stiffness and viscosity for fibrosis, steatosis and activity staging using shear wave elastography. J Hepatol 62(2):317-324. https://doi. org/10.1016/j.jhep.2014.09.020

Denisin AK, Pruitt BL (2016) Tuning the range of polyacrylamide gel stiffness for mechanobiology applications. ACS Appl Mater Interfaces 8(34):21893-21902. https://doi.org/10.1021/acsam i. 5 b09344

Engler A, Bacakova L, Newman C, Hategan A, Griffin M, Discher D (2004) Substrate compliance versus ligand density in cell on gel responses. Biophys J 86(1):617-628. https://doi.org/10.1016/ S0006-3495(04)74140-5

Engler AJ, Sen S, Sweeney HL, Discher DE (2006) Matrix elasticity directs stem cell lineage specification. Cell 126:677-689. https ://doi.org/10.1016/j.cell.2006.06.044

Geerligs M, Peters GWM, Ackermans PAJ, Oomens CWJ, Baaijens FPT (2008) Linear viscoelastic behavior of subcutaneous adipose tissue. Biorheology 45(6):677-688

Gong Z, Szczesny SE, Caliari SR, Charrier EE, Chaudhuri O, Cao $X$, Lin Y et al (2018) Matching material and cellular timescales maximizes cell spreading on viscoelastic substrates. Proc Natl Acad Sci. https://doi.org/10.1073/pnas.1716620115

Huang S, Ingber DE (2005) Cell tension, matrix mechanics, and cancer development. Cancer Cell 8(September):175-176. https ://doi.org/10.1016/j.ccr.2005.08.009

Hui L, Zhang J, Ding X, Guo X, Jiang X (2017) Matrix stiffness regulates the proliferation, stemness and chemoresistance of laryngeal squamous cancer cells. Int J Oncol 50(4):1439-1447. https://doi.org/10.3892/ijo.2017.3877
Ivkovic S, Beadle C, Noticewala S, Massey SC, Swanson KR, Toro LN, Bresnick AR, Canoll P, Rosenfeld SS (2012) Direct inhibition of myosin ii effectively blocks glioma invasion in the presence of multiple motogens. Mol Biol Cell 23(4):533-542. https://doi.org/10.1091/mbc.E11-01-0039

Kim D-H, Wirtz D (2013) Predicting how cells spread and migrate. Cell Adhes Migr 7(3):293-296. https://doi.org/10.4161/ cam. 24804

Klein EA, Yin L, Kothapalli D, Castagnino P, Byfield FJ, Xu T, Levental I, Hawthorne E, Janmey PA, Assoian RK (2009) Cell-cycle control by physiological matrix elasticity and in vivo tissue stiffening. Curr Biol CB 19(18):1511-1518. https://doi.org/10.1016/j. cub.2009.07.069

Kostic A, Lynch CD, Sheetz MP (2009) Differential matrix rigidity response in breast cancer cell lines correlates with the tissue tropism. PLoS ONE 4(7):e6361. https://doi.org/10.1371/journ al.pone. 0006361

Kraning-Rush CM, Califano JP, Reinhart-King CA (2012) Cellular traction stresses increase with increasing metastatic potential. PLoS ONE 7(2):e32572. https://doi.org/10.1371/journ al.pone. 0032572

Krouskop TA, Wheeler TM, Kallel F, Garra BS, Hall T (1998) Elastic moduli of breast and prostate tissues under compression. Ultrasonic Imaging 20(4):260-74

Leight JL, Wozniak MA, Chen S, Lynch ML, Chen CS (2012) Matrix rigidity regulates a switch between TGF-B 1 -induced apoptosis and epithelial-mesenchymal transition. Mol Biol Cell 23(5):781791. https://doi.org/10.1091/mbc.E11-06-0537

Levental I, Levental KR, Klein EA, Assoian R, Miller RT, Wells RG, Janmey PA (2010) A simple indentation device for measuring micrometer-scale tissue stiffness. J Phys Condens Matter Inst Phys J 22(19):194120. https://doi.org/10.1088/0953-8984/22/19/19412

Levental KR, Yu H, Kass L, Lakins JN, Egeblad M, Erler JT, Fong SFT et al (2009) Matrix crosslinking forces tumor progression by enhancing integrin signaling. Cell 139(5):891-906. https://doi. org/10.1016/j.cell.2009.10.027

Mih JD, Sharif AS, Liu F, Marinkovic A, Symer MM, Tschumperlin DJ (2011) A multiwell platform for studying stiffness-dependent cell biology. PLoS ONE 6(5):e19929. https://doi.org/10.1371/journ al.pone.0019929

Mih JD, Marinkovic A, Liu F, Sharif AS, Tschumperlin DJ (2012) Matrix stiffness reverses the effect of actomyosin tension on cell proliferation. J Cell Sci 125(Pt 24):5974-5983. https://doi. org/10.1242/jcs.108886

Mihai LA, Chin L, Janmey PA, Goriely A (2015) A comparison of hyperelastic constitutive models applicable to brain and fat tissues. J R Soc Interface 12(110):0486. https://doi.org/10.1098/ rsif.2015.0486

Nagano M, Hoshino D, Koshikawa N, Akizawa T, Seiki M (2012) Turnover of focal adhesions and cancer cell migration. Research article. Int J Cell Biol 2012:310616. https://doi. org/10.1155/2012/310616

Omari EA, Varghese T, Kliewer MA, Harter J, Hartenbach EM (2015) Dynamic and quasi-static mechanical testing for characterization of the viscoelastic properties of human uterine tissue. J Biomech 48(10):1730-1736. https://doi.org/10.1016/j.jbiom ech.2015.05.013

Paszek MJ, Zahir N, Johnson KR, Lakins JN, Rozenberg GI, Gefen A, Reinhart-King CA et al (2005) Tensional homeostasis and the malignant phenotype. Cancer Cell 8(3):241-254. https://doi. org/10.1016/j.ccr.2005.08.010

Pathak A, Kumar S (2012) Independent regulation of tumor cell migration by matrix stiffness and confinement. Proc Natl Acad Sci USA 109(26):10334-10339. https://doi.org/10.1073/pnas.1118073109 
Perepelyuk M, Chin L, Cao X, van Oosten A, Shenoy VB, Janmey PA, Wells RG (2016) Normal and fibrotic rat livers demonstrate shear strain softening and compression stiffening: a model for soft tissue mechanics. PLoS ONE 11(1):e0146588. https://doi.org/10.1371/ journal.pone. 0146588

Perepelyuk M, Terajima M, Wang AY, Georges PC, Janmey PA, Yamauchi M, Wells RG (2013) Hepatic stellate cells and portal fibroblasts are the major cellular sources of collagens and lysyl oxidases in normal liver and early after injury. Am J Physiol Gastrointest Liver Physiol. https://doi.org/10.1152/ajpgi.00222.2012

Plotnikov SV, Pasapera AM, Sabass B, Waterman CM (2012) Force fluctuations within focal adhesions mediate ECM-rigidity sensing to guide directed cell migration. Cell 151(7):1513-1527. https:// doi.org/10.1016/j.cell.2012.11.034

Pogoda K, Janmey PA (2018) Glial tissue mechanics and mechanosensing by glial cells. Front Cell Neurosci. https://doi.org/10.3389/ fncel.2018.00025

Pogoda K, Bucki R, Byfield FJ, Cruz K, Lee T, Marcinkiewicz C, Janmey PA (2017) Soft substrates containing hyaluronan mimic the effects of increased stiffness on morphology, motility, and proliferation of glioma cells. Biomacromol 18(10):3040-3051. https://doi.org/10.1021/acs.biomac.7b00324

Pogoda K, Chin L, Georges PC, Byfield FJ, Bucki R, Kim R, Weaver M, Wells RG, Marcinkiewicz C, Janmey PA (2014) Compression stiffening of brain and its effect on mechanosensing by glioma cells. New J Phys 16:075002. https://doi.org/10.1088/13672630/16/7/075002

Reiss-Zimmermann M, Streitberger KJ, Sack I, Braun J, Arlt F, Fritzsch D, Hoffmann KT (2015) High resolution imaging of viscoelastic properties of intracranial tumours by multi-frequency magnetic resonance elastography. Clin Neuroradiol 25(4):371-378. https ://doi.org/10.1007/s00062-014-0311-9
Safshekan F, Tafazzoli-Shadpour M, Abdouss M, Shadmehr MB (2017) Viscoelastic properties of human tracheal tissues. J Biomech Eng doi 10(1115/1):4034651

Tilghman RW, Cowan CR, Mih JD, Koryakina Y, Gioeli D, SlackDavis JK, Blackman BR, Tschumperlin DJ, Parsons JT (2010) Matrix rigidity regulates cancer cell growth and cellular phenotype. PLoS ONE 5(9):e12905. https://doi.org/10.1371/journ al.pone.0012905

Ulrich TA, de Juan Pardo EM, Kumar S (2009) The Mechanical rigidity of the extracellular matrix regulates the structure, motility, and proliferation of glioma cells. Can Res 69(10):4167-4174. https:// doi.org/10.1158/0008-5472.CAN-08-4859

Visscher MO, Burkes SA, Adams DM, Gupta A, Wickett RR (2016) Biomechanical properties of infantile hemangiomas: clinical stage and effect of age. Skin Res Technol Off J Int Soc Bioeng Skin (ISBS) 22(4):487-96. https://doi.org/10.1111/srt.12290

Webb K, Hlady V, Tresco PA (2000) Relationships among cell attachment, spreading, cytoskeletal organization, and migration rate for anchorage-dependent cells on model surfaces. J Biomed Mater Res 49(3):362-368

Zhang R, Ma M, Dong G, Yao R-R, Li J-H, Zheng Q-D, Dong Y-Y et al (2017) Increased matrix stiffness promotes tumor progression of residual hepatocellular carcinoma after insufficient heat treatment. Cancer Sci 108(9):1778-1786. https://doi.org/10.1111/cas.13322

Publisher's Note Springer Nature remains neutral with regard to jurisdictional claims in published maps and institutional affiliations. 